\title{
BEST PRACTICES IN CUSTOMS ADMINISTRATIONS: A PRELIMINARY EXPLORATORY STUDY
}

\author{
MELHORES PRÁTICAS EM ADMINISTRAÇÕES \\ ALFANDEGÁRIAS: UM ESTUDO EXPLORATÓRIO \\ PRELIMINAR
}

Data de submissão: 17/01/2014

Aceite: 10/11/2014

Cristiano Morini ${ }^{1}$

\begin{abstract}
This work focuses on the competitiveness seen by the customs procedures involved. Customs can be considered as a bottleneck in international logistics in some countries. Through an exploratory and bibliographical research, we could understand the main characteristics of the customs procedures in Brazil compared with the characteristics of countries considered as world reference. The analysis was based on information drawn from websites of the customs administrations of the countries that initiated the implementation of internationally accepted "good practices', according to criteria of the World Bank and other international organizations. It is crucial to note the best practices and benchmarking in the customs environment. Among the best practices observed, we highlight the electronic transmission of data, the analysis of risk based on prior information, cooperation at various levels, the use of information technology in transmission and registration procedures, compliance with the Revised Kyoto Convention, among others. Brazil has some actions targeted at best practices, but we need greater agility and coordination in the implementation of most of them.
\end{abstract}

Keywords: Competitiveness, customs, best practices, trade facilitation.

${ }^{1}$ Possui graduação em Relações Internacionais pela Universidade de Brasília - UNB, mestrado em Integração Latino - Americana pela Universidade Federal de Santa Maria - UFSM e doutorado em Engenharia de Produção pela Universidade Metodista de Piracicaba UNIMEP. Limeira. São Paulo. Brasil. E-mail: cristiano.morini@fca.unicamp.br 


\section{RESUMO}

O estudo enfoca a competitividade em termos de procedimentos alfandegários. A aduana ou alfândega pode ser considerada como um gargalo em alguns países em termos de logística internacional. Por meio de uma pesquisa exploratória e bibliográfica, o estudo apresenta as principais características de procedimentos aduaneiros no Brasil, comparados com países considerados de referência mundial na área. A análise está baseada em informação coletada de websites de administrações aduaneiras de países que iniciaram a implementação de "boas práticas" internacionalmente aceitas, de acordo com critérios definidos pelo Banco Mundial e outros organismos internacionais. É crucial observar melhores práticas no ambiente aduaneiro. Entre as melhores práticas observáveis, destacam-se a transmissão eletrônica de dados, a análise de risco baseada em informações prévias, a cooperação em vários níveis, o uso de tecnologia de informação na transmissão e registro de despachos, práticas relacionadas à Convenção de Quioto Revisada, entre outras. A administração alfandegária brasileira tem buscado atingir grande parte das boas práticas, mas é necessário maior agilidade e coordenação na sua implementação.

Palavras-chave: Competitividade, aduana, melhores práticas, facilitação comercial.

\section{INTRODUCTION}

Brazil is currently the 7th largest economy in the world. However, in terms of competitiveness, its position drops to the $58^{\text {th }}$ place, according to the World Competitiveness ranking, elaborated by the World Economic Forum and which involves 139 countries (Onaga \& Vital, 2011). In the study Trading Across Borders of the Doing Business 2013 ranking, produced by the World Bank, Brazil is in the 123rd position of a total of 133 economies. In the Logistics Performance Index (LPI) ranking, also from the World Bank, Brazil is located in the 82nd place in the ranking, in relation to customs procedures. The general characteristics that lead to the competitiveness analyses are addressed in this article. Brazil is situated on a low position in terms of competitiveness in the customs environment.

According to the World Economic Forum, there are nine factors related to competitiveness: institutions, infrastructure, macroeconomics, health and primary education, higher education and training, market efficiency, technological capacity, degree of sophistication of business and innovation (Onaga \& Vital, 2011).

The Brazilian customs administration is within the "institutions" factor. Represented by the Secretariat of the Federal Revenue of Brazil (RFB), this study identifies practices of the customs administration in line with some of the best global practices. However, largely, there are more customs controls in Brazil than necessary. The number of controls and records for the release of goods at the customs, whether for export or import, becomes an element that contributes to the loss of national competitiveness, which causes additional difficulties to the already high international competition.

This article aims to identify the competitive characteristics related to countries with best customs practices and their possible relationship with the Brazilian practices. According to the main objective, the focus is given to the customs situation of the country, within the larger context of logistics management. Customs procedures can hamper the flow of the Brazilian foreign trade, increasing the difficulty of forecasting and adding costs and time that do not add value. Another important point is the fact that the Brazilian economy has a long history of adopting high import tariffs, which still remain high in some important sectors of the Brazilian economy (Baumann \& Ceratti, 2012).

In this sense, we mapped the procedures linked to the Brazilian customs legislation, as well as the procedures adopted by countries considered as having the "best practices" in the control of flows by customs, in order to identify the aspects to be improved, to obtain a better performance in 
terms of competitiveness. The "best practices" are defined by a set of international organizations.

The method to be used to develop the research is the exploratory type. The exploratory method works with hypotheses. One hypothesis is that the customs procedures in Brazil require greater coordination (inter-agency and among other customs administrations of other countries) in order to ensure greater celerity in the monitoring, and it is also relevant Brazil's compliance to the Revised Kyoto Convention (concerning the simplification of customs procedures). Thus:

Hypothesis 1: customs procedures in Brazil require greater coordination and agility. The observation of best practices contributes to the management of change.

Hypothesis 2: Brazil has advanced in terms of good practice, but has not yet joined the Revised Kyoto Convention, which is a type of catalyst for customs changes.

The research to be used is the bibliographical and documentary type (see Table 1). Bibliographical as the research was done in specialized books, magazines and websites, and documentary as documents from international trade organizations were analyzed. "The main advantage of the bibliographical research lies in the fact that it allows the researcher to cover a much broader range of phenomena than they could search directly" (Gil, 1999: 65).

\section{Table 1: RESEARCH METHODS AND TECHNIQUES INVOLVED.}

- Exploratory Research: makes explicit the problem or constructs hypotheses. Involves bibliographical survey and analysis of examples that foster understanding.

- Bibliographical Research: performed from material already published, mainly consisting of books, articles, journals and materials made available on the Internet (official websites of customs administrations and rankings of international organizations and other institutions).

\section{COMPETITIVENESS}

The level of internationalization and interconnections between national and international businesses is increasing. According to Furtado (1999), countries that have the means to adapt to the new parameters are those that have a more cohesive and coherent economic fabric, with their own financial capacity, and they are able to face the instability characteristic of the international economy.

Cho et al. (2007) consider that the competitiveness of a nation is more significant when the competitors are concentrated in countries that have similar characteristics, since competitiveness implies a relative position among competitors in the same competitive group.

Fagerberg et al. (2007) also states that the term "competitiveness of countries" is relative, because there needs to be a comparative parameter, guided, in this case, in the analysis of other countries.

Benites \& Valério (2004) mention one of the most widely used concepts, which is proposed by Porter (1989), in which "competitiveness" is the skill or talent, resulting from knowledge gained, capable of creating and sustaining a superior performance to that developed by the competition. Benites \& Valério (2004) analyze that competitiveness can be seen and understood in various ways and can be assigned according to the macroeconomic outlook, boosted by variables such as interest and exchange rates, deficits and Government policies, low expenditures with workforce, natural resources and, above all, differences in administrative practices.

This same conception mentioned by Benites and Valério (2004) is also addressed by Xavier (2000), designated as competitiveness-effect (CE), biased in exports. Xavier (2000) points to the fact that the CE derives from macroeconomic factors (exchange rates, interest rates, wages, tax burden, among others) and systemic changes (in infrastructure, workforce qualification, 
transaction costs, for example). Competitiveness-effects, in this case, are lined in dynamic changes in the focus of the structure of exports and imports.

More broadly, the World Economic Forum (WEF) worked on the creation of a Global Competitiveness Index $(\mathrm{GCl})$. Although each index is motivated by ideological issues whose parameters, form of data collection and analysis can be contested, the $\mathrm{GCl}$ defines competitive economies as those that have factors that boost the increase of productivity, in which the present and future prosperity is built.

Within this context, competitiveness is defined as the set of institutions, policies, and factors - these are part of the 12 pillars of competitiveness, which includes infrastructure, education, health, labor market, among others - that determines the level of productivity of a country. In other words, as shown, the more competitive economies tend to be able to produce higher levels of income for citizens and the productivity level also determines the rate of return obtained from investments - physical, technological and human - in an economy (Mia et al., 2010).

Another approach and form of identification of competitive variables, elaborated by the IMD World Competitiveness Center, argues that growth, wealth or economic dimension are not the only elements that ensure the competitiveness of a country. The study considers that broader measures are necessary for the production of a global index, which should include elements such as human skills, entrepreneurial spirit or a favorable business environment, which are also an integral part of success (IMD, 2012).

Önsel et al. (2008) believe that the survivability of companies, and their ability to have or build competitive advantage in the global market, depends on the efficiency of national public institutions, excellent educational, health and communication infrastructure, as well as national policy and economic stability. On the other hand, a favorable macroeconomic environment alone does not guarantee a high level of national competitiveness, unless organizations create products and services with high productivity at the microeconomic level. This way, Önsel et al. (2008) conclude that, in the concept of "competitiveness", there must be a set of micro- and macroeconomic characteristics that determine the level of productivity and competitiveness of a country.

In parallel, the Department of Competitiveness and Technology (DECOMTEC) of the Federation of Industries of the State of São Paulo (FIESP) conceptualizes the term "competitiveness" as (Índice, 2010:19):

(...) ability of a country to create conditions for companies and organizations in it to produce the greatest possible welfare for its citizens and to let them grow over time in relation to the citizens of other countries. Thus, competitiveness can be understood as the ability of a country to maintain and renew a set of attributes that promote business development and thus leverage the production and distribution of wealth.

From the point of view of industrial competitiveness, industrial diversification can also be considered an advantage, as points out the Technological Research Institute - IPT (2008), since it stimulates the technical progress. This is because the introduction of new technologies brings benefits that can be identified as cost reduction or increased productivity, or the differentiation/launching of new products that also generates a differential of industrial competitiveness and prosperity for the society.

Table 2 presents a sample of authors addressing the subject "competitiveness", consid- 
ering the micro- or macroenvironment.

Table 2: SAMPLE TABLE-SUMMARY ABOUT AUTHORS AND CONCEPTS OF COMPETITIVENESS

\begin{tabular}{|c|c|}
\hline Authors & Main contributions \\
\hline Cho et al. (2007) & $\begin{array}{l}\text { Competitiveness is measured taking into account nations that have similar } \\
\text { characteristics and compete in similar industries. }\end{array}$ \\
\hline Fagenberg et al. (2007) & $\begin{array}{l}\text { "Competitiveness of nations": relative term (comparison between other } \\
\text { countries) and with double meaning (economic well-being and commercial } \\
\text { performance). }\end{array}$ \\
\hline Porter (1989) & Knowledge that create and sustain superior performance in the competition. \\
\hline Benites and Valério (2004) & $\begin{array}{l}\text { Macroeconomic outlook (exchange rates and interest, deficits and Govern- } \\
\text { ment policies, low expenditures with workforce, natural resources, differ- } \\
\text { ences in administrative practices). }\end{array}$ \\
\hline Xavier (2000) & $\begin{array}{l}\text { Macroeconomic factors and systemic changes (infrastructure, workforce } \\
\text { qualification, transaction costs, etc.). }\end{array}$ \\
\hline $\begin{array}{l}\text { World Economic Forum } \\
\qquad(\mathrm{GCl})\end{array}$ & $\begin{array}{l}\text { Competitiveness: set of institutions, policies and factors that determine the } \\
\text { level of productivity of a country. }\end{array}$ \\
\hline IMD (2012) & $\begin{array}{l}\text { In addition to growth, wealth and economic dimension, elements such as } \\
\text { human skills, entrepreneurial spirit or favorable business environment are } \\
\text { necessary. With its competitiveness Yearbook - "The competitiveness of } \\
\text { nations" -, it measures economic performance, Government and business } \\
\text { efficiency and infrastructure. }\end{array}$ \\
\hline Önsel et al. (2008) & $\begin{array}{l}\text { Depends on the efficiency of public institutions, educational, health and } \\
\text { communication infrastructure, national policy and economic stability; all } \\
\text { this aligned with the characteristics of the micro- and macro-economic en- } \\
\text { vironment. }\end{array}$ \\
\hline DECOMTEC (ÍNDICE, 2010) & $\begin{array}{l}\text { Ability of a country to encourage business development and leverage the } \\
\text { production and distribution of wealth. With its Competitiveness of nations } \\
\text { Index (IC-FIESP), it analyzes the growth of Brazilian competitiveness in face } \\
\text { of the competing countries. }\end{array}$ \\
\hline IPT (2008) & $\begin{array}{l}\text { Competitiveness based on industrial diversification, stimulating the techni- } \\
\text { cal progress and generating a differential of industrial competitiveness and } \\
\text { prosperity for the society. }\end{array}$ \\
\hline
\end{tabular}

Source: Our own elaboration.

\subsection{Competitive Structure}

Based in the introduction about the meaning of the term "competitiveness", several factors interfere, directly or indirectly, in the formulation of a competitive strategy, which aims to relate the company (internal environment) with the external environment in which it operates. Such a strategy is what will differentiate one company from another, since external forces are common to all companies.

According to Porter (2004), although the relevant environment is very broad, covering both social and economic forces, the main aspect of the environment of the company is the industry or industries in which it competes, and the industry structure is important in the international competition.

This way, the internal environment is restricted to the country, considering Brazil, and the external environment covers the entire globe. This way, the external environment refers to the world market, according to Furtado (1999:64): "it is much more than a potentiality that is offered to the big ones; it is also a restriction that presents itself in front of each company that does not have the necessary resources to penetrate it."

With regard to the role of the Government, which is the focus of this article, Farina 
(1997) mentions a conclusion drawn by North \& Weingast (1989: 156): "for economic growth to occur, the sovereign or the Government should not only establish the relevant set of rights, but also build a reliable commitment to ensure it." Given this, the Government has an important role in regulating and structuring the business environment as a whole, enabling its development and growth, and thus having higher chances to compete internationally.

Benites \& Valério (2004), according to the approach of Porter (1989), mention that the competitive advantage originates from basic, primary and support activities practiced by the company in an environment of a given Government. That is, the competitive advantage originates from the activities developed in the production, operations, logistics, services, management skills, infrastructure, technology and purchases.

A stable macroeconomic environment is important both for business and for global competitiveness. As soon as a country becomes more competitive, productivity increases, causing the country to reach a new stage of development.

According to the Global Competitiveness Index (GCI), Brazil appears in the 48th position, which means an improvement compared to the 2010-2011 index, in which it appeared in the 58th position, according to the $\mathrm{GCl}$. This gain in competitiveness, as shown by the index, is due to the progress made in the search for macroeconomic stability, liberalization and openness of the economy, as well as in the reduction of the income inequality. Despite this improvement, Brazil faces certain problems. According to $\mathrm{GCl}$, government efficiency is low due to excessive government regulation and unnecessary expenses. In addition, the transport infrastructure is poor, seen as one of the main restraints for competitiveness, as well as the quality of education (Blanke et al., 2012).

In the global scenario, companies compete at the international level and, this way, the country to which it belongs has an important role, since the Government will support all other pillars responsible for the country's economic development and its competitiveness in the international market. Excessive bureaucracy and regulations, corruption, lack of transparency and reliability, among other things, slow down the process of economic development and prevent competitive gains.

\section{LOGISTICS AND CUSTOMS GOOD PRACTICES}

In this section, we present the aspects related to logistics, its definition and practices, taking into account the customs practices of the countries considered as those with "good practices". The globalization of markets caused new challenges with regard to logistics, involving supplier management, quality management, time management and others, and, in this context, suppliers and customers are shattered into global value chains (OCDE, 2011).

For Christopher (2009: 234), the fundamental concept of logistics can be defined as:

the strategic management process in the purchase, transport and storage of raw materials, parts and finished products (in addition to the related information flows) by the organization and its marketing channels, so that current and future profitability is maximized by the delivery of orders at the lowest associated cost.

In addition, logistics involves the acquisition of supplies, inventory management, marking and packing, handling and storage, transportation and distribution, all in a dynamic form of information management and process planning as a whole (Pires, 2009).

Basic activities related to a logistic system are as follows (Houlihan, 1985; Chopra \& Meindl, 2003; Pires, 2009; Ballou, 2009): 
- Acquisition of inputs (production support for producers/suppliers);

- Stock and Storage (pre- and post-distribution);

- Marking and packing (including cargo unitization when necessary);

- Transport and physical distribution (in different stages: origin, transit and destination), passing through the controls of borders and customs;

- Pre-submission storage and inventory;

- Consumer Delivery;

- Information Management;

- Management of collaborations and partnerships between the links in the chain.

According to the Logistics Performance Index, also produced by the World Bank, the term "logistics" has been evolving since the 19 century and currently this concept has advance to the supply chain (or supply chain management, SCM), involving the necessity of collaboration across all links in the chain, as well as sharing responsibilities and risks.

Supply chain management is based on the logistics structure and seeks to create coordination links between the processes of other organizations existing in the channel, that is, suppliers and customers, and the organization itself. This way, logistics is integral and essential to the success of the supply chain management.

The supply chain is characterized by Sunil (2011) as all parties involved, directly or indirectly, in the completion of a customer order. It also includes, in addition to the manufacturer and suppliers, shippers, warehouses, retailers and the customers themselves.

In the current period, the internationalization of markets increasingly incited the competition between countries, becoming relevant the talk about logistics and SCM in the global scope, since the aspects and practices concerning these two processes directly affect the competitiveness of countries practicing it. This increase of sources of global competition was driven by the reduction of barriers to trade and the development of a global transport infrastructure (Christopher, 2009; Dornier et al., 2000; Waters, 2010).

Globally, according to Morini \& Leoce (2011), SCM must be concerned with challenges that add up related to the transposition of barriers and to the compliance of customs and legal controls of countries. Customs cannot represent a bottleneck, following the theory of constraints of Goldratt. The speed of the slower "link" ends up determining the result of the full speed on the global supply chain. The high speed of all "links" can be neutralized by the slow speed of a given "link". In certain countries, the customs represents the slower "link", the bottleneck.

According to Arvis et al. (2012), global supply chains are very varied and complex, and thus the efficiency of the logistics relies on Government services, investment and policies (factors considered as important for the competitiveness of a country). According to Arvis et al. (2012), the construction of infrastructure, the development of a system for the regulation of transport services and the development and implementation of efficient procedures of customs clearance are areas where governments play an important role.

Bowersox \& Closs (2001) state that global operations increase the cost and complexity of logistics, as they increase the uncertainty resulting from greater distances, longer cycles and lower market knowledge, and in addition they reduce the ability to control, given the use of intermediation associated with government intervention in areas such as customs requirements and restrictions on trade. 


\subsection{Benchmarking and Supply Chain Management}

Due to the high competition scenario, companies end up facing different problems than that existing internally at the country's borders where they are located, since, internationally, there are greater risks involved, which are most likely to cause disruption and reduce predictability (Dornier et al., 2000). Accordingly, it is appropriate to analyze the procedures and practices arising from other countries with the purpose of observing the "best practices".

The "best practices" are related to policies, concepts, models, processes, activities, initiatives, information, mode of organization for tasks, people and technologies. The "best practices" provide a comprehensive approach to the planning, implementation and operation of optimal levels of performance. "Bbest practices" demonstrate the ability to achieve superior results, which have been demonstrated to be more effective in practice and considered as of leadership, or of exceptional model that must and can be followed by others, saved the organizational, cultural and geographical particularities of each country (WCO, 2012).

This learning with existing practices from other countries is made possible by the use of benchmarking, featured, in the customs environment, according to the Handbook of Benchmarking, as "a systematic process that uses research, analysis and comparison to identify and learn from the good or best practices from other organizations" (WCO, 2012: 8). Thus, the technique enables a greater understanding of what could be modified and/or improved in the country. Benchmarking is based on the assumption that it is important to learn from organizations perceived as having the best practices (Piotrowicz et al., 2011).

For Camp (1998), benchmarking is the search for the best practices that will drive a company to maximize its business performance and is characterized as a positive, proactive and structured process that drives changes in operations that will be reflected in the superior performance and superior competitive advantage.

Within a global customs context, the Handbook of Benchmarking considers that the goal of benchmarking is to "improve the efficiency and effectiveness of the national customs administration, through the comparison of similar processes or procedures performed by others, and then identify and implement the best practices" (WCO, 2012).

On the other hand, according to the Handbook of Benchmarking, benchmarking is not an instrument of execution, that is, it does not cause authorities to obey certain laws or other measures. On the contrary, it can be used for the development of the abilities of customs administrations, contributing to the continuous improvement, for example. In addition, benchmarking does not need to be used only for the solution of existing problems, but it can also be used to recognize best practices prior to the introduction of new systems or procedures (WCO, 2012).

Among the types of benchmarking that can be found, we can mention competitive benchmarking as the most relevant to the question of the best customs practices, since this is characterized by the knowledge on and learning of the best practices from the competitors, in order to measure the basic characteristics and functions to achieve them.

Christopher (2009: 279), focusing on competitive benchmarking, presents a definition applied to the term:

constant measurement of the products, services, processes and practices of the company in relation to the standards of the best competitors and other companies recognized as leaders. (...) The measures chosen for comparison must directly or indirectly impact the customers' evaluation regarding the performance of the company. 
Therefore, the use of this tool enables the learning with those who present a higher competitive level.

\subsection{Trade Facilitation and Customs Practices}

The World Trade Organization (WTO) defines "trade facilitation" as being based on the achievement of more efficient business practices and the reduction of costs of the cross-border trade for the benefit of exporters, importers and consumers. According to the WTO, the goal of the negotiations is to clarify three articles of the General Agreement on Tariffs and Trade (GATT) of 1947, which are related to the transit of goods, fees and formalities (documents and procedures), and transparency of laws and regulations. Their goal, according to the WTO, is to facilitate border procedures, the release and clearance of goods (WTO, 2012).

In relation to the subject of trade facilitation, the Organization for Economic Cooperation and Development (OECD) complements that the losses that companies suffer in the management of international supply chains - such as border delays, lack of transparency and predictability, complicated documentation requirements and other cumbersome customs procedures - may exceed the costs of tariffs. Thus, improvements in border procedures and trade facilitation would produce reductions in transaction costs, in addition to having a significant positive effect on trade flows (Milner et al., 2005; Njinkeu et al., 2007; Pomfret, 2010).

In Brazil, the customs administration (Federal Revenue of Brazil) has developed the PMAB project (Plan of Modernization of the Customs Administration of Brazil), whose objectives include: to improve customs processes, to ensure the correct and uniform application of the legislation and to provide excellent services to society, thus contributing to increase the Brazilian competitiveness internationally. For the formulation of this article, we raised the strategic objectives of the customs, which can be observed in Table 3 . There are certain goals, such as numbers $6,13,14$ and 15, for example, which are not exclusive of customs.

Table 3: STRATEGIC OBJECTIVES OF THE CUSTOMS ADMINISTRATION

To subsidize the formulation of tax policy and foreign trade, considering:

Tax Policy: Use of customs taxes on the tax policy of the Country, emphasizing its regulatory bias.

Foreign Trade Policy: inclusion of the Country in the global standards of international trade, emphasizing its control and speed of flow of trade bias.

To lead and intervene in the processes of integration with Government agencies and national and international agencies related to foreign trade practices, aimed at finding solutions to logistical bottlenecks.

To intensify the role of the Customs in combating organized crime.

To strengthen the institutional image of the Customs, in the context of the RFB, and to promote awareness of its user. To promote the attendance of excellence to users of Customs.

To optimize the control and collection of tax credit.

To improve the quality and productivity of customs activities.

To increase the effectiveness of surveillance and repression of customs offenses.

To simplify, standardize and fasten customs control.

To elevate the quality of case files and recovery of credit recorded.

To promote improvement, simplification and consolidation of federal Customs and Tax legislations and to standardize their interpretation.

To improve the People Management policy of RFB.

To increase the effectiveness, efficiency and efficacy in the budget, financial and patrimonial management and management of goods seized.

To improve the policy of the management of information technology services, aiming at the innovation, quality, efficiency and effectiveness of services.

To implement excellence management in Customs, in the context of RFB. 
Source: Brazilian Federal Revenue Office (2007).

The strategic objectives of the Brazilian customs administration are an attempt to tune with worldwide reference reports. According to the annual study produced by the World Bank - known as Doing Business 2013 -, outdated and inefficient border procedures, inadequate infrastructure and lack of reliability at the logistic service level add transaction costs and cause delays. In addition, the more expensive and time-consuming the processes of export or import, the harder for local businesses to be competitive and achieve international markets (The World Bank, 2012). The Doing Business ranking also has a separate section exclusively about the Trading Across Borders. Figure 1 illustrates the Brazilian position (in red) against the other 40 economies of more economic development. Brazil is the seventh world economy, but, competitively, it is in a very unfavorable position in this ranking (in other rankings, Brazil has a similar position, occupying the most unfavorable positions).

Figure 1: Doing Business 2013 Ranking x Trading Across Borders Classification (2013)

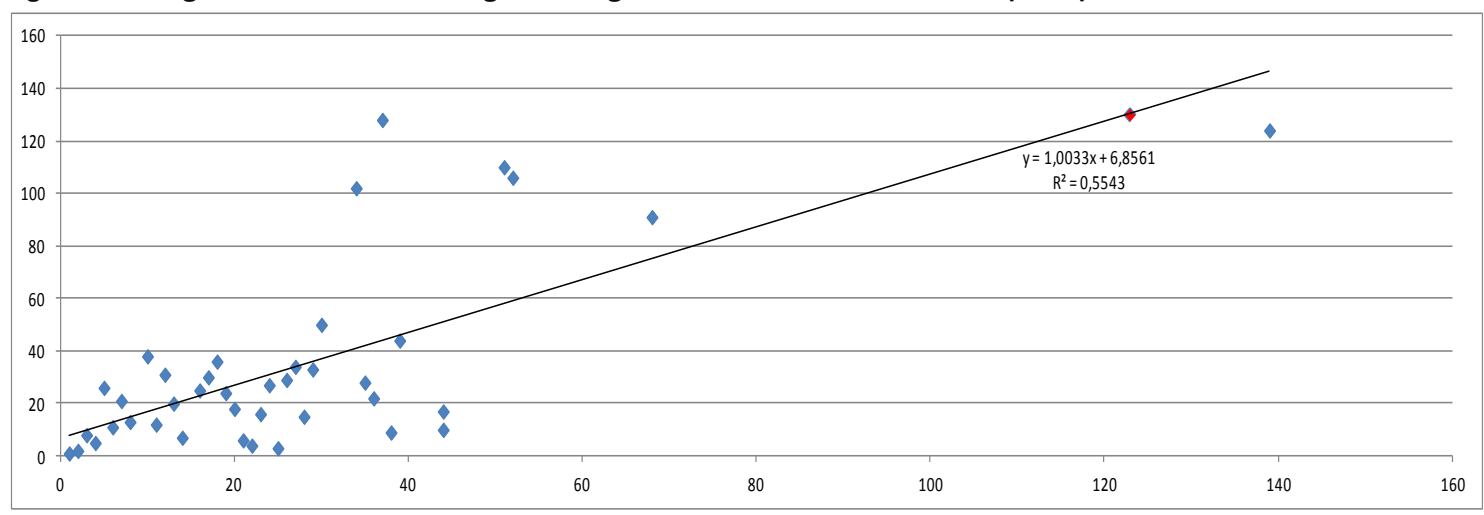

Source: our own elaboration (from the World Bank's rankings)

In this commented study, Doing Business, there is a specific chapter called "Trading Across Borders." It presents indicators that allow the analyses of the results of trade across borders and the identification of positive reforms adopted by certain countries. In this sense, Table 4 was produced aiming to illustrate the good practices registered in the period from 2004 to 2012, based on the analysis of the annual Doing Business studies, produced by the World Bank.

Table 4: GOOD CUSTOMS PRACTICES

\begin{tabular}{|c|c|}
\hline Period of & Aspects \\
\hline $2004-2012$ & $\begin{array}{l}\text { Setting of time limits for customs clearance (quantifiable goals). } \\
\text { Introduction of electronic transmission of data. } \\
\text { Elimination of commercial licenses. } \\
\text { Introduction of risk analysis for physical inspections, as well as customs risk manage- } \\
\text { ment techniques. } \\
\text { Elimination of pre-shipment inspection. } \\
\text { Improvements in port and road infrastructure. } \\
\text { Automatic debit of taxes in checking account. } \\
\text { Cooperation and agreements between countries with borders. } \\
\text { Cooperation between agencies involved in ports. } \\
\text { Improvement of port procedures. } \\
\text { Reduction in the number of documents. } \\
\text { Introduction of paperless processes. } \\
\text { Introduction of single window. }\end{array}$ \\
\hline
\end{tabular}


Source: adapted from Doing Business Database (our own elaboration, 2013)

In addition, according to the Logistics Performance Index, logistics efficiency and trade facilitation are on the agenda of decision makers, private companies and international organizations, and many developing countries have pressed for reforms to increase the efficiency of the supply chain and to facilitate trade and transport services (Arvis et al., 2012).

The best practices used by other customs administrations can contribute to the change management in the national environment, using benchmarking. The subject of change management is not central in this article, but touches the subject of benchmarking. Cummings \& Worley (2008) show a contribution on the subject of change management. From the good customs practices, mentioned in Table 4, we could analyze the practices already observed in Brazil (Table 5), as well as identify the points that still can be incremented.

Table 5: GOOD CUSTOMS PRACTICES IN BRAZIL

Improvement of consultation procedures on tax classification.

Improvement of physical facilities of the RFB - Border Service Unit.

Restructuring of navigation activities.

Creation of the National Risk Management Center.

Development of computerized systems for the control of postal items and travelers' goods.

Implementation of the Unified Tax Regime - RTU.

System of Registers (Customs Brokers - Importers - Exporters).

Automation of work processes.

Enabling of Intervening Parties.

Use of technological resources in physical conference works.

Automated control of customs transit

Special customs regimes (greater integration of the country with the outside world).

Deployment of the RADAR system (Registration and Tracking of the Performance of Customs Intervening Parties).

Search for uniformity of procedures of customs supervision.

Performance of control and verification of the origin of imported goods based on Certificates of Origin.

Source: Our own elaboration (Modernization of the Customs Administration of Brazil, 2011; Federal Revenue Office website, 2013).

\section{RESULTS AND DISCUSSIONS}

Based on information taken from websites of the customs administrations of the countries that initiated the implementation of "good practices," according to the countries indicated in the mentioned study produced by the World Bank, Table 6 was prepared from indications of good practices, crossing the information from the Doing Business Report with the information made available on the websites of the customs administrations studied. With this cross-check, we identified some of the best customs practices adopted by these countries (Table 6). It is important to highlight that part of the best practices are also related to the issue of safety in the management of international supply chains, as most of the risks involved in the management of international chains is related to the issue of security, especially after 2001, in which measures have been taken to ensure that international trade is not used as a tool of terrorist acts, among other concerns. The subject of security is included in the topic "risk management", which is a 
broad subject and is considered, in this article, as a customs risk.

Table 6: BEST CUSTOMS PRACTICES (REFERENCE: DOING BUSINESS 2013 RANKING)

\begin{tabular}{l|l}
\hline Country (Placing) & Main practice \\
\hline Singapore (1st) & $\begin{array}{l}\text { Trade facilitation programs (TradeNet and TradeXchange) and security of } \\
\text { supply chain trade }\end{array}$ \\
\hline Hong Kong (2nd) & $\begin{array}{l}\text { Single clearance system for each means of transport, control of trade with } \\
\text { focus on Strategic Commodities, process certification system and supervi- } \\
\text { sion of money service operators }\end{array}$ \\
\hline South Korea (3rd) & Transport declaration system and e-clearance \\
\hline Denmark (4th) & Contact Committee that seeks to better understand the needs of customers \\
\hline United Arab Emirates (5th) & Feedbacks from customers to discover and solve problems \\
\hline Finland (6th) & Integrated system of customs clearance (ITU) and Cargo Transit (NCTS) \\
\hline Estonia (7th) & Electronic system to facilitate the collection of the Estonian tax \\
\hline Sweden (8th) & $\begin{array}{l}\text { Program for customs clearance (TDS), risk management plan (Stairway Concept) } \\
\text { and communication tool between the Swedish Customs and trade (Info97) }\end{array}$ \\
\hline Panama (9th) & Integrated Foreign Trade System (SICE) of single window type.
\end{tabular}

Source: Our own elaboration (2013), from the websites of the customs administrations mentioned.

Analyzing the reform and practices adopted by the selected countries, we can realize that most improvements are based on building a good infrastructure and the improvement of processes and procedures related to the customs environment. The infrastructure and the level of service provided by the customs authorities are therefore considered as indispensable elements for the improvement of the competitive level of a country. In this sense, countries increasingly seek reforms aimed at increasing the efficiency in the supply chain and facilitating trade, in order to gain competitiveness in the entire chain.

In the Brazilian case, infrastructure is still a challenge, because it results in higher logistical costs and inefficient patterns of interregional and international trade, moving away the country from global value chains. According to $\mathrm{GCl}$, the most problematic areas and that deserve to be highlighted, regarding the hard aspect (of the infrastructure subject), are the quality of the infrastructure of ports, roads, railways, air transport and cellular telephony (MIA et al., 2010). Thus, an improvement at the "hard" infrastructure level is a good practice, both for a more developed and efficient customs system and for a general improvement in the Brazilian competitiveness level.

In addition to the hard aspects, the soft aspects (or the more "subtle" ones of infrastructural improvements) also need to be incremented, such as the reduction of the number of documents required in import and export orders, definition of time limits for customs clearance, introduction of paperless processes, introduction of a single window, among others, which show that one of the main problems of loss of competitiveness of Brazil is due to the high bureaucratization of the customs procedures. This information could be confirmed by crossing data from the competitiveness reports of the institutions mentioned (World Bank, World Economic Forum, IMD and FIESP, among others) with the Plan of Modernization of the Customs Administration of Brazil (PMAB).

In Brazil, the factors that need to be worked out primarily, in relation to the practice of business and its relationship with the Government, highlighted by $\mathrm{GCl}$, are concentrated basically on the tax regulation, level of taxes, corruption and government bureaucracy. Bureaucracy is also considered a priority by the FIESP Index of Competitiveness of Nations. Brazil occupies the 82nd position (among 155 countries) in efficiency in customs clearance, taking approximately 5.47 days, on average, for the customs clearance, while Korea takes 1 day and hile approximately 1.32 days (Coelho, 2009). Hence, the initiative by the World Customs Organization (WCO) to seek 
broad membership, including Brazil, to the Revised Kyoto Convention (RKC).

The RKC is a legal instrument produced in 1973, proposed by the World Customs Organization (WCO) in order to simplify customs procedures, as well as establish procedures common to the customs of the world for the facilitation of international trade. Revised in 1999, it entered into force in 2006, with the ratification of 78 countries.

Among the RKC goals, we can highlight (among others) (Morini \& Leoce, 2011):

- Development of uniform practices and procedures around the world;

- Development of standards suitable for customs control;

- Customs training to respond to major changes in the business environment;

- Reduced costs of processing of information on customs, benefiting economic operators and Governments;

- Contribution in terms of competitiveness gains, including for increased exports.

The Kyoto Convention is called "revised", which sets it apart from the original Convention, as it establishes the best practices in the following topics (Ireland \& Matsudaira, 2011):

- Risk management;

- Controls based on audits of internal controls;

- Information prior to the arrival of the cargo;

- Information technology;

- Coordinated interventions and physical conference as an exception;

- Consulting of economic operators;

- Resource system in customs matters, in a simplified form.

The Brazilian tax and customs administration, represented by the Secretariat of the Federal Revenue of Brazil (RFB), has already conveyed the request for the compliance to the Convention. Currently, the request for compliance is being processed by the Brazilian Executive until it goes to the National Congress, according to verbal information from the Undersecretary of customs and foreign relations of Brazil's Revenue. Brazil's compliance to the Revised Kyoto Convention should also help to implement good customs practices in Brazil, an issue fundamental to contribute to the national competitiveness gains, as well as function as a type of catalyst for the necessary changes in customs management.

Cooperation between the customs of the countries is also a practice of trade facilitation, which provides greater efficiency and effectiveness in the logistics and customs processes. The issue of customs cooperation with the private sector is also one of the good international practices that Brazil has sought to follow. In the case of Brazil, the Procomex Institute has been the intermediary between the customs administration and the private sector. Some results may be observed in the review of the specific legislation on the foreign trade in Brazil, as recently occurred with the publishing of a new legislation on temporary admission.

The use of "paperless" procedures is still not in circulation in Brazil, although some pilot procedures have been used in cargo handling by national ports.

According to the PMAB of the Federal Revenue, a critical aspect of the Brazilian customs administration focuses on the subject of change management, since, according to the report, there is a need for better planning in the implementation of institutional efforts, a lack of involvement of public workers in institutional programs and projects, a lack of effective communication 
between the areas (due to the complexity and great coverage of the structure of customs in Brazil), a lack of consensus on goals and guidelines of the customs activities, inappropriate performance measurement control of public workers, and conflict of opinions on important subjects such as trade facilitation and customs control, among others (Federal Revenue, 2007).

In this sense, benchmarking presents itself as a good practice for Brazil to develop, seeking to increase its national competitiveness and improve customs and logistics procedures, with significant contribution to the subject of change management.

\section{FINAL REMARKS}

The Government has an important role on the creation and maintenance of the ability of the country in creating conditions favorable to business growth, acting as a facilitator in obtaining competitive gains for companies and for the country.

Although Brazil has advanced in terms of tuning with some of the best world practices, it is necessary to move more quickly in the implementation of change management. It makes no sense in inaugurating a National Risk Management Center, for example, if there is still no prior sharing of information between customs. Hypothesis 1 is confirmed, in the sense that there are good practice initiatives, but they are insufficient in Brazil, if it is observed the dynamics of highly competitive markets.

The speed in the implementation of the changes may contribute to the better positioning of the Brazilian customs in terms of competitiveness assessment, considering the different rankings. Every ranking system or methodology is questionable. However, Brazil is, currently, in positions well below the potential of the national economy, in different rankings, hence the relevance to study the subject.

It is also necessary to observe, through benchmarking, that good practices are aligned with the use of paperless procedures, the high level of service provided by the customs authorities, the combat to all forms of informality, among others, which are practices in line with the Revised Kyoto Convention. Benchmarking practices embrace change, but they should be used carefully and consider that each country possesses a reality, history, culture, geography and other peculiarities. Brazil's compliance can contribute to the change management required in the customs environment, also proving the raised hypothesis 2 . All countries mentioned with best customs practices are signatories to the Convention.

As a suggestion for future research studies, it would be useful to examine whether the best practices have contributed to the attraction of foreign direct investments (FDI), and if this attraction is greater in more competitive countries, from international rankings, tracing a parallel in relation to the world's largest economies and their relative competitive position. In addition, they can study how the subject of change management is inserted in the planning and actions of the Brazilian customs administration. 


\section{REFERENCES}

ARVIS, J. F.; MUSTRA, M. A.; OJALA, L.; SHEPHERD, B.; SASLAVSKY, D. Connecting to Compete: Trade Logistics in the Global Economy. The Logistics Performance Index and Its Indicators. Washington: The World Bank, 2012.

BALLOU, R. H. Logística Empresarial: transportes, administração de materiais e distribuição física. São Paulo: Atlas, 2009, 444 p.

BAUMANN, R.; CERATTI, R. 2012. A Política Comercial dos BRICS: seu entorno e seus efeitos para o Brasil. Disponível em: http:// www.ipea.gov.br/portal/images/stories/PDFs/ boletim_internacional/120328_boletim_ internacional09.pdf. Acesso em: 2 abr. 2012.

BENITES, A. T.; VALERIO, L. M. Competitividade - Uma abordagem do ponto de vista teórico. In: IV JCEA, Campo Grande, Oct., 2004.

BLANKE, J.; SALA-I-MARTIN, X.; BILBAOOSORIO, B.; CROTTI, R.; HANOUZ, M. D.; GEIGER, T.; KO, C. The Global Competitiveness Index 2012 - 2013: Strengthening Recovery by Raising Productivity: Geneve: World Economic Forum, 2012.

BOWERSOX, D. J; CLOSS, D. J. Logística empresarial: o processo de integração da cadeia de suprimento. São Paulo: Atlas, 2001, $540 \mathrm{p}$.

CHO, D. S.; MOON, H.C.; KIM, M. Y. Characterizing international competitiveness in international business research: A MASI approach to national competitiveness. Seoul: Elsevier, 2007.

CHOPRA, S; MEINDL, P. Gerenciamento da cadeia de suprimentos. São Paulo: Prentice Hall, 2003, 465 p.

CHRISTOPHER, M. Logística e gerenciamento da cadeia de suprimentos: criando redes que agregam valor. São Paulo: Cengage, 2009, 367 p.

COELHO, J. R. R. Índice Fiesp de competitividade das nações e agenda de competitividade para o Brasil. São Paulo: FIESP, 2009. Índice Fiesp de competitividade das nações e agenda de competitividade para o Brasil. São Paulo: FIESP, 2011.

CUMMINGS, T. G; WORLEY, C. G. Organization Development \& Change. Mason: Cengage, 2008, $772 \mathrm{p}$.

DEPARTAMENTO de Competitividade e Tecnologia (DECOMTEC). Índice Fiesp de competitividade das nações 2010, Fiesp, São Paulo, 2010.

DORNIER, P. P.; ERNEST, R.; FENDER, M.; KOUVELIS, P. Logística e operações globais: Texto e Casos. São Paulo: Atlas, 2000.

FAGERBERG, J.; SRHOLEC, M.; KNELL, M. The Competitiveness of Nations: Why Some Countries Prosper While Others Fall Behind. Norway: Elsevier, 2007.

FARINA, E. M. Q.; AZEVEDO, P. F.; SAES, M. S. M. Competitividade: mercado, estado e organizações. São Paulo: Editora Singular, 1997.

FURTADO, J. Mundialização, reestruturação e competitividade: a emergência de um novo regime econômico e as barreiras às economias periféricas. In: Novos Estudos CEBRAP, São Paulo, n. 53, 1999.

GIL, A. C. Métodos e técnicas de pesquisa social. São Paulo: Atlas, 1999.

HOULIHAN, J. International supply chain management. International Journal of Physical Distribution and Materials Management, Columbus, v. 1, n. 5, p. 22-38, 1985.

IMD. 2012. World Competitive Index Press Release. Switzerland climbs onto the podium, May 2012. Disponível em: <http://www. 
imd.org/research/publications/wcy/upload/ CHPress_ReleaseUK.pdf $>$. Acesso em: 3 ago. 2012

IRELAND, R.; MATSUDAIRA, T. Reform instruments, tools, and best practices approaches. In: McLinden, Gerard; Fanta, Enrique; Widdowson, David; Doyle, Tom (editors), Border Management Modernization. Washington: The World Bank, 2011.

MIA, I.; SALA-I-MARTIN, X.; BLANKE, J.; HANOUZ, M. D.; GERIGER, T. The Global Competitiveness Index 2010 - 2011: Looking beyond the Global Economic Crisis. Geneva: World Economic Forum, 2010.

MILNER, C.; MORRISEY, O.; ZGOVU, E. Trade Facilitation in Developing Countries. Centre for Research in Economic Development and International Trade, University of Nottingham, Nottingham, n. 08, 2005.

MORINI, C.; LEOCE, G. Logística Internacional Segura: operador econômico autorizado e a gestão de fronteiras no século XXI. São Paulo: Atlas, 2011.

NJINKEU, D.; WILSON, J.; FOSSO. P. F. Trade facilitation: what is it and how does it help? AERC collaborative research workshop on Export Supply Response, Capacity Constraints in Africa. Dar es Salaam: Tanzania, 2007.

ORGANIZATION for Economic Co-Operation and Development (OECD). Interconnected Economies: benefiting from global value chains. Paris: OECD, 2011.

ONAGA, M.; VITAL, N. A busca por um Brasil competitivo. São Paulo: Abril Publishing, 2011.

ÖNSEL, Ş.; ÜLENGIN, F.; ULUSOY, G.; AKATAS, E.; KABAK, Ö.; TOPCU, Y. I. A new perspective on the competitiveness of nations. Istambul: Elsevier, 2008.

PIOTROWICS, W.; CUTHBERTSON, R.; ISLEI, G. Performance measurement and benchmarking in the supply chain: literature review. Oxford:
Oxford, 2011.

PIRES, S. R. I. Gestão da Cadeia de Suprimentos. São Paulo: Atlas, 2009.

POMFRET, R. Trade Facilitation and the Measurement of Trade Costs, Journal of International Commerce, Economics and Policy, v. 1, n. 1, p. 145-163, 2010.

PORTER, M. E. Estratégia competitiva: técnicas para análise de indústrias e da concorrência. Rio de Janeiro: Elsevier, 2004

\section{A vantagem competitiva das}

nações. Rio de Janeiro: Elsevier, 1989.

RECEITA Federal do Brasil. Plano de Modernização da Administração Aduaneira do Brasil. Brasília: Secretaria da Receita Federal do Brasil, 2010.

RUTKOWSKI, K. Best practices in logistics and supply chain management. The case of Central and Eastern Europe. In: WATERS, D. Global Logistics: new directions in supply chain management. London: KoganPage, 2010.

ŞENER, S.; SARIDOGAN, E. The effects of science - technology - innovation on competitiveness and economic growth. In: The 7th International Strategic Management Conference, Turquia, 2011.

SILVA, T. N.; DIAS, M. F. P.; ROSA, N. P.; MENDONÇA, E. S. Priorização dos critérios competitivos das operações baseado nos recursos estratégicos. Revista de Economia $e$ Gestão, v. 9, n. 1, jan/jun. 2011.

SUNIL, C. Gestão da cadeia de suprimentos: estratégia, planejamento e operações. São Paulo: Pearson Prentice Hall, 2011.

THE WORLD BANK. Doing Business in 2006: Creating Jobs. Washington, D.C: The World Bank, 2007.

Doing Business 2007: How to reform. Washington, D.C: The World Bank, 2008. 
Doing Business 2008. Washington,

D.C: The World Bank, 2009.

Doing Business 2009. Washington, D.C: The World Bank, 2010.

. Doing Business 2010: Reforming through difficult times. Washington, D.C: The World Bank, 2011.

Doing Business 2011: Making a difference for entrepreneurs. Washington, D.C: The World Bank, 2012.

Doing Business 2012: Doing business in a more transparent world. Washington, D.C: The World Bank, 2013.

Doing Business 2013: Smarter regulations for small and medium-size enterprises. Washington, D.C: World Bank Group, 2014.

XAVIER, C. L. Padrões de especialização $e$ competitividade no comércio exterior brasileiro, Tese (Doutorado), Instituto de Economia, Universidade estadual de Campinas, Campinas, 2000.

WATERS, D (ed.). Global Logistics: new directions in supply chain management. London: Kogan Page, 2010.

WORLD Customs Organization (WCO). Customs International Benchmarking: benchmarking manual. Brussels: WCO, 2012.

WORLD Trade Organization (WTO). Trade Facilitation. Disponível em: http://www.wto. org/english/tratop_e/tradfa_e/tradfa_e.htm. Acesso em: 22 mar. 2013. 